\title{
Research on the Countermeasures of the Vocational College Students' Comprehensive Ability based on the Training Practice Base
}

\author{
Zhang Yuchen \\ Henan Mechanical and Electrical Vocational College, Xinzheng, Henan, China
}

\begin{abstract}
The students 'comprehensive vocational ability is the key to improve the quality of vocational teaching practice, and the construction and role play of the training practice base is the basis of students' comprehensive vocational ability. Vocational colleges should be multi-pronged approach, actively expand the construction approaches of the training practice base, and widely establish the campus training base, the training base outside college and the practice bases outside college, as well as to deep cooperation with enterprises and to build the superiority major by schools and enterprises. At the same time, it should enable students to participate in real jobs and work processes. In the process the comprehensive training is the goal, the actual project is a carrier, by this way education reform can take a breakthrough and can ensure the strict management, can achieve real results.
\end{abstract}

Keywords - the higher vocational education, practical teaching system, training practice base, comprehensive vocational ability

\section{基于实训实习基地的高职学生综合能力提升对策研究}

\author{
张玉臣
}

河南机电职业学院, 新郑, 河南, 中国

摘 要 培养学生的综合职业能力是提高高职实践教学质量的关键, 而实训实习基地的建设和作用发挥是培养学生综合职业能力 的基础。高职院校应当多管齐下, 积极拓展实训实习基地建设的途径, 广泛建立校内实训基地、校外实训基地、校外实习基地, 以及 深化校企合作, 实现优势专业的校企共建。与此同时, 还应当使学生真正参与到工作岗位和工作流程中, 以综合实训为目标, 以实际 项目为载体, 以教学改革为突破, 以严格管理为保障, 达到真实训练的效果。

关键词＼cjkstart高等职业教育，实践教学体系，实训实习基地，综合职业能力

\section{1. 引言}

近年来, 在高等职业教育迅猛发展的形势下, 面对企 业对职业岗位和生源需求结构发生的变化, 暴露出高职学 生的职业能力不强, 理论知识与实践不匹配, 不能适应社 会的实际需求, 出现了毕业生就业难的问题。问题的解决 之道在于，根据社会需求变化适时调整人才培养模式，充 分发挥实践教学在高职教育中的核心作用, 以实训实习基 地为基础, 打破 “工学两层皮” 现象, 切实培养提高高职 学生的综合职业能力, 实现就业零过度的目标。

\section{2. 实训实习基地是提升实践教学质量的关键}

高职教育质量的直接体现在高职学生的就业能力上。 而高职教育质量的提高, 不仅是高职实践教学体系的建设
和完善, 更主要的是依赖于真实职场环境下实践教学质量 的提升, 并体现于学生在处理生产、建设、管理、服务一 线实际问题时综合职业能力的提升。因此, 在实践教学中, 设法提高学生的综合职业能力, 才是开展实践教学的目标 任务。

首先, 应当充分发挥实践教学体系的体系化作用。实 践教学体系主要由教学实验、综合实训、顶岗实习三个关 键环节构成。教学实验训练的是学生的单项技能和专项能 力, 综合实训培养的是学生的综合技能和基本职业素养, 顶岗实习是学生在就业前的全面适应性训练。因此, 要提 高学生的综合职业能力, 教学实验是基础, 综合实训是关 键，顶岗实习 是提升。 
其 次, 应构建综合职业训练的环境和场所, 使学生切 身体验真实的工作环境、工作岗位和工作过程, 并在体验 中学习, 参与中训练, 这是培养学生的专业技术能力、思 维方法和职业素养的基本保障。因此从这个层面说, 构建 以真实职业环境为特征的实训实习基地是提高实践教学质 量的关键问题。

从教育的价值上看, 实训实习基地构建的是一种实践 性、开放性、职业性的教学环境。当前高职院校都在努力 打造彰显自身特色的实践教学体系, 所谓特色, 所反映的 正是实训实习基地的 建设和管理特色。为了充分发挥实训 实习基地在培养学生综合职业能力上的功能, 高职院校应 当不断增加投入, 多管齐下, 全面建设各类实训实习基地, 满足实践教学量的要求; 同时, 还需要以真实训练为基础, 使实训实习基地发挥出实战的作用。

\section{3. 多管齐下, 拓展实训实习基地建设途径}

在增加投入的基础上, 实训实习基地的建设应当多管 齐下, 深入挖掘校内外各类资源, 尤其是要打好 “校企合 作” 和 “工学结合” 两张牌。只有建立更多的实训实习基 地, 才能为深化实践教学奠定最基本的保障。

\section{1 引进企业资源, 建立校内实训基地}

依托校内各类实验教学中心而建立起来的校内实训基 地通常可以用于满足基本的课程实验和训练, 但要开展综 合性实训, 则要依托相关企业建立校内生产性实训基地。 教育部在 2007 年 颁布的《国家示范性高等职业院校建设 推荐预审标准 (试行)》中提出: 校内生产性实训是由学校 提供场地和管理, 企业提供设备、技术和师资支持, 校企 合作联合设计和系统组织实训教学的实践教学模式。这种 实践教学模式的最大优势是在校内构建真实的生产环境, 实现教学做的统一。为了构建校内实训基地, 高职院校可 以充分利用自身的知名度, 与设备生产商和用人企业建立 三方合作关系。由设备生产商提供免费的设备使用服务 (甚 至捐赠), 建立符合实训要求的产品生产线; 由 用人企业 帮助建立生产和管理环境, 并在生产、管理、教学等各方 面提供指导, 高职院校则可以通过产品生产和人才培养作 为合作中的回报。

\section{2 联合学校周边企业, 建立校外实训基地}

高职院校以其专业和人才优势带动着周边企业的发 展, 周边企业也可以为学校教学发展提供丰富的资源, 从 而形成一种相互依托的关系。双方的合作可以很好的满足 各自的需求, 形成一种 共赢的局面。企业可以提供良好的 实训环境, 但需要能够胜任工作任务的高技能人才, 学校
是人才培养基地, 但急需企业所提供的职业环境和实训机 会。联合学校周边企业建立校外实训基地, 对高职院校而 言, 具有专业、地缘、人才认可等方面的优势, 因此是一 种比较容易实现的途径。在双方建立的合作协议中, 企业 应当预留 特定的岗位和工作任务, 以满足学校对实训的需 要; 而学校则应当提供源源不断的人才资源, 以满足企业 生产的连续性。双方如能建立长久合作关系, 企业将可以 不断降低人力资源成本, 而学校则能够不断提升实践教学 质量。

\section{3 实习与就业相结合, 在生源省份建立校外实习基地}

高职学生在毕业前所进行的专业实习或顶岗实习是适 应岗位需要、提升综合实践能力的最佳实践方式。在《教 育部关于全面提高高等职业教育教学质量的若干意见》(教 高[2006]16 号) 中曾经明确提出: “高等职业院校要保证 在校生至少有半年时间到企业等用人单位顶岗实习。”本 科生和研究生相比, 高职院校毕业生的就业竞争力主要在 二三线城市。因此, 高职院校可以避开北京、上海、广州 等一线城市, 而选择在二三线城市与当地企业进行广泛合 作, 逐步建立和积累一大批实习基地。实习基地与就业基 地相结合, 不仅有利于学生在实习中实现就业, 反过来, 当毕业生在用人企业中表现出色, 将进一步促进更多的企 业吸纳本校毕业生前来实习, 使实习与就业形成良 性互 动。

\section{4 深化校企合作, 选择优势专业实现校企共建}

高职院校面向用人企业 实现订单式培养是一种理想 的实践教学模式。企业获得的是 “下得去、留得住、用得 上” 的人才, 而高职院校不仅获得了稳定的实习环境和实 习岗位, 并且在人才培 养规格、“双师型” 师资队伍等方 面都将得到保障。高职院校要与企业全面实现这种模式并 不容易, 因此, 学校可以选择优势专业进行订单式培养。 这种培养模式的 建立有赖于高职院校积极吸引企业参与 办学, 把自身的教学优势纳入到企业发展格局中, 形成利 益共同体。在这种良好局面下, 企业才能够把高职院校作 为自己的教育培训基地, 纳入企业的职教计划, 主动负责 地同院校一起制定人才培养方案, 依据企业的职业岗位和 岗位能力要求, 明确学生未来的就业岗位要求。

\section{4. 深入参与, 发挥实训实习基地教学功能}

提升实践教学的质量, 不仅是要构建真实的职业环境, 还应当使学生真正参与到工作岗位和工作流程中, 从而达 到真实训练的效果。 


\section{1 以综合训练为目标 分科教学中的实践教学}

主要针对某一类技能, 属于基础知识学习和基础技能 训练, 学生学到的技能是片面的、割裂的。但在现实岗位 中, 经常遇到是复杂的、综合性的技能问题, 因此, 实训 和实习中为了体现职业环境和工作岗位的实际要求, 就要 以综合运用各项技能解决实际问题的综合训练为主。实训 实习基地所提供的真实职业环境, 也有利于开展 综合技能 训练, 培养学生解决实际问题的能力, 形成良好的职业素 养。有研究者提出应建立 “毕业实习” “毕业设计” 和 “顶 岗实习” 三位一体的综合实训模式, 也是通过实训实习基 地提升综合职业能力的一种实践。

\section{2 以实际项目为载体}

在实践教学中, 要使学生真正参与到工作过程中, 就 要以项目为载体, 在完成项目的过程中锻炼其工作能力、 学习能力、团队意识、质量意识、组织与纪律观念等。例 如, 计算机专业的学生可以参与软件项目研发项目, 摄像 专业的学生可以参与电视节目制作项目。在项目设计上, 应尽可能采用实际生产项目, 这些项目比教师设计的训练 项目更具有实践意义, 学生更能体验到工作岗位上的真实 要求。在项目实施中, 一个非常重要的事情是任务分工。 除了按照固有的岗位分工, 还要根据教学目的区分任务复 杂度。学员的参与, 既是一个生产过程, 也是一个学习过 程。对每一位学生来说, 项目训练都应当体现从新手到熟 手, 从简单到复杂的过程一一先承担简单任务, 积累经 验, 提高能力, 然后再逐步承担复杂的任务。

\section{3 以教学改革为突破}

为了充分发挥实训实习 基地在实践教学中的重要作 用, 不仅需要在课程体系中增加实践教学的比重, 还应当 建立与之相适应的教学模式。传统的 “先学习, 再实习” 的教学模式容易导致实 践与教学相脱节, 应当突破这种教 学模式的限制, 建立一种工学交替的教学模式。所谓 “工 学交替” 就是课堂学习与实训实习交替进行, 使理论学习 与实践操作有机 结合。一般是第一学年在学校学习, 其中 安排一个月到企业进行认知实习, 第二学年半年在校学习,
半年在校内或校外实训基地进行专业实习, 第三学年半年 在学校 学习, 半年到企业顶岗实习。

\section{4 以严格管理为保障}

实训实习基地的建设是一个长期积累的过程, 应当有 一种保障机制使它长效发挥作用。因此, 需要加强对实训 实习基地的全面管理，包括从规划、建设、运行、产出、 评价各个方面, 有条件的话, 还可以借鉴 ISO9000 标 准化 体系, 实施标准化管理。在管理的重点上, 首先, 应加强 实训实习基地的组织管理。成立诸如基地建设管理委员会 的机构, 负责统筹管理学校各类实训实习基地 的规划、建 设和监督工作, 协调处理师生以及相关企业在基地运作过 程中所遇到的各类问题。其次, 应加强实训实习基地的制 度建设。包括与实训基地相关的工作场景、工作流程、工 作标准、人员配置等生产管理体制以及安全操作规程, 组 织机构及其管理制度和管理方法和质量管理标准、道德规 范和行为准则等。再次, 应加强 “双师型” 教师队伍建设。 从企业中遴选精英人才进入教师队伍, 加强对实践教师的 培训和培养, 使他们成为能够指导学生进行实践训练和职 业发展的专业教师。

\section{参考文献(References)}

[1] Wu Xuemin. Idea of Vocational Education Training Base Construction and Strategies. Chinese Vocational and Technical Education .2011 (33)

[2] Guo Jian. Creating School-Enterprise Cooperation Platform to Realize the Depth of Vocational Education "Four Cooperation." China Adult Education .2012 (5)

[3] Liu Ronghong. Higher Vocational Colleges Based on School Enterprise Cooperation "Three-In-One" Practice Base Model. Continuing Education Research.2012 (4)

[4] Huang Jinzhu. Vocational Training Mode of the Teaching Practice Base. Continuing Education Research .2012 (4)

[5] Zheng Yongjie. The Forum of the Standardized Administration Construction for the Four Integrated Vocational Training Base. Vocational Education Forum .2012 (5) 